\title{
A parvo-like virus in cultured redclaw crayfish Cherax quadricarinatus from Queensland, Australia
}

\author{
Rachel O. Bowater ${ }^{1, *}$, Max Wingfield ${ }^{2}$, Andrew Fisk $^{1}$, Kelly M. L. Condon ${ }^{1}$, \\ Angela Reid ${ }^{1}$, Howard Prior ${ }^{3}$, Elizabeth C. Kulpa ${ }^{1}$ \\ ${ }^{1}$ Queensland Department of Primary Industries, Animal and Plant Health Service, Oonoonba Veterinary Laboratory, \\ PO Box 1085 Townsville, Queensland 4810, Australia \\ ${ }^{2}$ Queensland Department of Primary Industries, Bribie Island Aquaculture Research Centre, \\ PO Box 2066, Bribie Island, Queensland 4507, Australia \\ ${ }^{3}$ Queensland Department of Primary Industries, Animal Research Institute, 665 Fairfield Road, \\ Yeerongpilly, Queensland 4105, Australia
}

\begin{abstract}
In the summer of 1999/2000, an epizootic occurred in cultured juvenile redclaw crayfish Cherax quadricarinatus on one commercial crayfish farm in northern Queensland, Australia. Mortalities occurred over 4 wk, with up to $96 \%$ cumulative mortalities in 2 earthen ponds stocked with juveniles. The crayfish were weak, anorexic and lethargic. A transmission trial was conducted, using filtered, cell-free extract prepared from infected crayfish as inoculum. The disease was reproduced, with on-going mortalities occurring in inoculated crayfish over 55 d. Experimentally inoculated crayfish showed gross signs of malaise, anorexia and disorientation before dying. Two types of intranuclear inclusion bodies (INIBs) were seen in tissues of endodermal, ectodermal and mesodermal origin by light microscopy with haematoxylin and eosin (H\&E) stained sections. 'Early'-stage INIBs were eosinophilic, rounded and located centrally within slightly enlarged nuclei while 'late'-stage INIBs were well-rounded and deeply basophilic. The gills, cuticular epithelium and epithelial cells of the foregut, midgut and hindgut were the most heavily infected tissues. By transmission electron microscopy, virions with an average diameter of $19.5 \mathrm{~nm}$ were seen within electron-dense granular inclusion bodies within enlarged nuclei of both naturally and experimentally infected crayfish. The size of the virions and cytopathology are consistent with characteristics of viruses in the Family Parvoviridae. This is the first reported case of mass mortality caused by a parvo-like virus infection in C. quadricarinatus.
\end{abstract}

KEY WORDS: Cherax quadricarinatus · Virus · Parvo-like virus · Disease $\cdot$ Aquaculture $\cdot$ Crayfish · Pathology Resale or republication not permitted without written consent of the publisher

\section{INTRODUCTION}

The redclaw crayfish Cherax quadricarinatus is a freshwater crayfish that naturally inhabits many inland river systems and billabongs in the Gulf of Carpentaria. Redclaw have been cultured in Queensland for over $15 \mathrm{yr}$, and the industry has slowly expanded since its commencement. Redclaw are cultured semi-intensively in several states of Australia including Queensland, and have been exported for culture to Latin America, Africa, Papua New Guinea, China and Taiwan (Medley et al. 1994).

*E-mail: rachel.bowater@dpi.qld.gov.au
Several viruses have been described from farmed Cherax quadricarinatus. These include Cherax quadricarinatus bacilliform virus (CqBV) (Anderson \& Prior 1992), Cherax Giardiavirus-like virus (CGV) (Edgerton et al. 1994), spawner-isolated mortality virus (Owens \& McElnea 2000), a putative gill parvovirus and a reolike virus (Edgerton et al. 2000). A systemic parvo-like virus has been described from a different species of freshwater crayfish, Cherax destructor, from a single moribund crayfish that was collected in South Australia (Edgerton et al. 1997). To date, none of these crayfish-infecting viruses, in the absence of other infectious agents, have been documented to cause mass mortalities on commercial redclaw farms. Sub- 
clinical viral infections have been reported (Edgerton et al. 1994, 1995, 2000, Edgerton \& Owens 1999), but crayfish with these infections have usually been coinfected with bacterial and/or other pathogens. Mass mortalities in pond-reared redclaw have so far been caused by bacterial diseases including vibriosis (Eaves \& Ketterer 1994) and those due to infections with rickettsiales-like organisms (Ketterer et al. 1992).

In December 1999 and January 2000, 1 redclaw crayfish farm in Queensland, Australia, reported higher than average mortalities in 2 earthen ponds stocked with juvenile crayfish Cherax quadricarinatus. Cumulative mortalities of up to $96 \%$ occurred over 2 mo. Histopathological examination of diseased crayfish revealed intra-nuclear inclusion bodies that resembled those associated with parvo-like viral infections. In February 2000, on-going mortalities occurred in other ponds on this farm stocked with adult crayfish. There was an estimated $50 \%$ loss in total farm production, due to losses of juvenile and adult crayfish and the farm subsequently closed down for a total destocking and pond disinfection. A detailed disease investigation was carried out to determine the cause of the mortalities.

The results and findings from the investigation, including histopathology, electron microscopy and a transmission trial, are presented. We also discuss the possible effects that this virus may have on the redclaw crayfish farming industry in Australia.

\section{MATERIALS AND METHODS}

Field specimens. In January 2000, a redclaw crayfish farm in northern Queensland, Australia, was visited in response to a report of on-going mortalities of juvenile redclaw over December 1999/January 2000. Five diseased redclaw crayfish were collected from the affected earthen ponds, fixed in Davidson's solution (Lightner 1996) and submitted to the Oonoonba Veterinary Laboratory, Townsville, Australia, for histological examination.

In February 2000, a detailed disease investigation was conducted to determine the cause of further ongoing mortalities that had occurred in other earthen ponds stocked with adult crayfish. A total of 47 crayfish were sampled from 4 earthen ponds on the farm for histopathology. They included healthy and moribund adult crayfish from 2 new ponds, and juvenile crayfish from the 2 ponds that showed mortalities over December 1999/January 2000. Four of the crayfish that were sampled from the ponds that showed chronic mortalities over the December 1999/January 2000 period were also sampled for bacteriological examination. Haemolymph was aspirated aseptically from the heart and plated onto selective media including blood agar and marine agar supplemented with vitamins. The plates were incubated at $25^{\circ} \mathrm{C}$ for $24 \mathrm{~h}$, then subcultured for identification using API 20 NE strips (bioMerieux).

A further 4 moribund crayfish were sampled from the same 2 ponds that showed mortalities over the December 1999/January 2000 period for examination by transmission electron microscopy (TEM). Cuticular epithelium was dissected directly from the cephalothorax, chopped finely and fixed directly in $2.5 \%$ glutaraldehyde for $1 \mathrm{~h}$. Several gill filaments were also removed and processed in the same way. These tissues were then washed twice in $0.1 \mathrm{M}$ cacodylate buffer at $\mathrm{pH} 7.2$ for $10 \mathrm{~min}$ and then stored at $4^{\circ} \mathrm{C}$. The tissues were then processed routinely for TEM (Hayat 1970).

All crayfish collected for histopathology were preserved by injection of Davidson's solution into the cephalothorax and tail. The cuticle of the cephalothorax was split longitudinally along the dorsal and ventral midline to facilitate penetration of fixative into the underlying organs and tissues. The cephalothorax was severed from the abdomen, and the pieces preserved in Davidson's solution for 24 to $48 \mathrm{~h}$, prior to histological processing. Crayfish tissues were then processed routinely for histology (Bancroft \& Stevens 1990). Tissues were stained with haematoxylin and eosin (H\&E). Special stains were prepared and included Feulgen's, phloxine-tartrazine, Giemsa and Brown \& Brenn's gram (Bancroft \& Stevens 1990).

In situ hybridisation. The crayfish farm was close to several prawn farms. It is known that certain species of penaeid prawns cultured in Australia have endemic parvo-like viral infections (Paynter et al. 1985, Roubal et al. 1989). To exclude the possibility that this virus was a marine prawn virus, in situ hybridisations were performed on selected paraffin-embedded tissue sections of crayfish that were identified as infected with the parvo-like virus from histological examination. Sections were cut at $5 \mu \mathrm{m}$ and adhered to silanetreated (3-aminopropyltriethoxy-silane; Sigma) glass slides and left for $1 \mathrm{~h}$ at $60^{\circ} \mathrm{C}$. Imported commercial DiagXotics test kits specific for the marine prawn viruses infectious hypodermal and haematopoietic necrosis virus (IHHNV) (IHHNV ShrimProbe \#IHHNV-IS) and hepatopancreatic parvo-like virus (HPV) (HPV ShrimProbe \#HPV-IS) were used on these sections. IHHNV and HPV in situ hybridisations were performed according to the protocol of the manufacturer.

An in situ hybridisation was also done using the 400 bp digoxygenin (DIG)-labelled probe developed for the detection of spawner-isolated mortality virus (SMV) in black tiger prawns Penaeus monodon (Owens et al. 1998). The probe was kindly provided by 
Dr. L. Owens and the protocol was as previously described for use with shrimp tissue sections (Owens et al. 1998). Sections were counterstained with Bismarck Brown, dehydrated and mounted in Mount-Quick.

Transmission trial. Experimental animals and equipment: Redclaw crayfish, 40 to $50 \mathrm{~g}$, were purchased from a commercial redclaw farm in Queensland that had not experienced any disease epizootics over the previous 12 mo. The crayfish were grossly healthy and robust on arrival at the laboratory. Five crayfish were randomly selected from the group and sacrificed for histological examination, prior to the commencement of the trial. The crayfish were stocked at 10 crayfish per $180 \mathrm{l}$ aquarium and acclimatised for $2 \mathrm{wk}$ prior to the commencement of the trial.

All aquaria and equipment used in the transmission trial were disinfected prior to use with sodium hypochlorite at $30 \mathrm{mg}^{-1} \mathrm{l}$ for $24 \mathrm{~h}$, rinsed several times with town water, sun-dried and then refilled with fresh clean water. Town water was used to supply each aquarium holding experimental crayfish. Town water was pumped into a reservoir tank, then dechlorinated with sodium thiosulfate at $1 \mathrm{mg}^{-1} \mathrm{l}$ and let stand for $3 \mathrm{~d}$, before use. Twelve $180 \mathrm{l}$ aquaria were used in the transmission trial. Each aquarium was fitted with 2 internal filters (coral rubble and filter wool medium), each connected to an air stone. Water quality in each aquarium was monitored weekly by measuring nitrite and ammonia concentrations. A 50\% water exchange was done once a week in each aquarium. Filters were removed from each aquarium once a week, cleaned, then replaced. Uneaten food and debris were removed from each aquarium every $3 \mathrm{~d}$. Water temperature in each aquaria was measured daily and ranged from $26 \pm 0.5$ to $30 \pm 0.5^{\circ} \mathrm{C}$ over the $76 \mathrm{~d}$ of the transmission trial. The room housing the 12 aquaria was centrally heated at $30^{\circ} \mathrm{C}$. All crayfish were fed with commercial crayfish pellets, at $4 \%$ body weight, or to satiation, in the mornings and evenings. Crayfish in each tank were visually assessed before and after feeding, for signs of activity and health.

Preparation of infected tissue ultrafiltrate: Infected tissue ultrafiltrate was prepared from the gills and cuticular epithelium of several frozen cephalothoraxes of Cherax quadricarinatus known to be infected with the parvo-like virus (confirmed by histology) and collected during the disease investigation. One gram of tissue was harvested, cut into $5 \mathrm{~mm}^{2}$ pieces, then homogenised in a Heidolph Diax 900 Homogeniser at a 1:4 ratio with homogenising solution (phosphate buffered saline pH 7.0 containing $2 \mathrm{ml}^{-1} \mathrm{l}$ of 4 -hexylresorcinol from Sigma Chemical, H6250). The homogenate was centrifuged in an Eppendorf Centrifuge at $6000 \mathrm{rpm}(3284 \times g)$ for $30 \mathrm{~min}$ at $4^{\circ} \mathrm{C}$ to remove coarse cellular debris and the supernate was further clarified by centrifugation at $12000(15294 \times g) \mathrm{rpm}$ for $30 \mathrm{~min}$ at $4^{\circ} \mathrm{C}$ before being filtered through a $0.45 \mu \mathrm{m}$ syringe filter into a sterile container for storage as a $5 \mathrm{ml}$ aliquot at $-80^{\circ} \mathrm{C}$. One drop of the filtered supernatant was plated onto blood agar and tryptic soy agar and incubated at $25^{\circ} \mathrm{C}$ for $48 \mathrm{~h}$ to confirm absence of bacterial contamination. Control, non-infected ultrafiltrate was prepared from the gills and cuticular epithelium of several healthy frozen cephalothoraxes obtained from the same farm. The same methodology used to prepare the infected ultrafiltrate was used to prepare the noninfected ultrafiltrate.

Experimental design: The transmission trial design included 3 treatment groups: a pathogen injected group, a non-infected tissue injected (injected control) group, and a non-injected control group. Forty crayfish were assigned to each treatment group that consisted of 4 replicates of 1 aquarium containing 10 crayfish (i.e. a total of 12 aquaria containing 120 crayfish). The aquaria were shelved on 3 sides of a room, with 4 per side, 2 on the top shelf and 2 on the bottom. They were separated by $40 \mathrm{~cm}$ and glass covers were placed over each. Each aquarium was randomly numbered for treatment protocol.

The pathogen injected group received an intramuscular injection of $0.1 \mathrm{ml}$ of infected ultrafiltrate into the right lateral side, between abdominal segments 1 and 2, using a sterile $1 \mathrm{ml}$ syringe with a 25 gauge needle. Crayfish in the injected control group received an intra-muscular injection of $0.1 \mathrm{ml}$ of uninfected ultrafiltrate in the same manner. All crayfish were subsequently held for $76 \mathrm{~d}$ with daily removal of dead and diseased crayfish. Crayfish were considered diseased if they showed gross signs of lethargy, did not respond to external stimuli, did not have a tail flick response, and were weak or disorientated. They were fixed by injection of Davidson's solution into the cephalothorax, submerged in Davidson's solution for 24 to $48 \mathrm{~h}$, then transferred to $70 \%$ ethanol and processed routinely for histology. At the end of the transmission trial, all remaining crayfish were killed and processed in the same manner.

\section{RESULTS}

\section{Farm epizootic/clinical disease}

\section{Clinical signs and history}

Diseased crayfish collected during the epizootic were anorexic and weak, had soft shells and did not respond with tail flicking during handling. Many were found at the pond edge and in bait traps. Some had a 
light orange discolouration of the carapace and a few had distinctive orange spots on it.

The water quality, including dissolved oxygen and $\mathrm{pH}$, was within normal limits. The crayfish were fed a standard commercially available crayfish pellet. The farmer had been collecting dead crayfish from the affected ponds and feeding them to crayfish in adjacent ponds.

\section{Histopathology}

The principal lesion was intranuclear inclusion bodies in cells of endodermal, ectodermal and mesodermal origin. Two different types of inclusion bodies were identified. 'Early'-stage intra-nuclear inclusion bodies (INIBs) were smaller, eosinophilic inclusion bodies in cell nuclei that appeared normal, or were only slightly enlarged. These inclusions did not stain with Feulgen's or phloxine-tartrazine stains. 'Late'-stage INIBs were large, prominent inclusion bodies that filled most of the markedly enlarged nuclei (Fig. 1). They were basophilic (blue) with H\&E stain, and red with Feulgen's and phloxine-tartrazine stains.

The gills, cuticular epithelium, foregut, midgut and hindgut epithelium, and connective tissue were the most heavily infected (Fig. 1). Less commonly infected were the antennal gland, haematopoeitic tissue, epithelial cells of the seminiferous tubules and interstitial tissue of the ovary. No inclusion bodies were detected within hepatopancreatocytes, neurones or the heart.

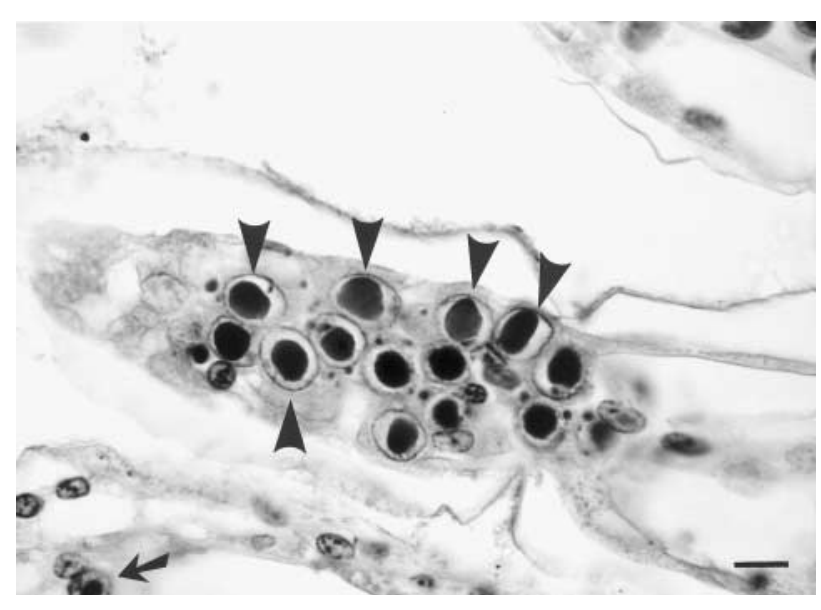

Fig. 1. Cherax quadricarinatus. Gill of crayfish infected with the parvo-like virus. Gill epithelial cell nuclei are markedly enlarged with a large basophilic inclusion (arrowheads). Note the 'early'-stage intranuclear inclusion body at the bottom left (arrow). H\&E. Scale bar $=14 \mu \mathrm{m}$
Bacteriology

A mixed flora of bacteria was isolated from the haemolymph of 3 of the 4 crayfish sampled. They included Aeromonas sobria, Alcaligenes sp., Bacillus spp., Citrobacter freundii, Corynebacterium sp., Edwardsiella tarda, Enterobacter agglomerans, Klebsiella pneumoniae, Moraxella sp., micrococci, Pseudomonas maltophilia, and Pseudomonas spp.

\section{Electron microscopy}

TEM of infected cells showed that 'late'-stage INIBs consisted of electron-dense masses (Fig. 2). There was margination of chromatin with displacement of the host cell nucleolus. At higher magnification, the electrondense masses were seen to consist of numerous hexagonal, parvo-like viral particles with a mean diameter of $19.5 \mathrm{~nm}(\mathrm{n}=50 \pm 0.2)$ (Fig. 3).

\section{In situ hybridisation}

The redclaw crayfish tissues tested negative for IHHNV and HPV using the DiagXotic test kits and negative for SMV using the $400 \mathrm{bp}$ DIG-labelled probe.

\section{Transmission trial}

\section{Clinical signs}

Diseased crayfish were observed only in the pathogen-injected treatment group. They displayed gross signs of lethargy, weakness, disorientation, anorexia and a red discolouration of the carapace before dying. They avoided other crayfish and sheltered in habitats provided in the aquaria or in tank corners and lacked aggression when challenged by other crayfish. They did not respond to tapping on the aquarium, whereas healthy crayfish rapidly moved away.

On post mortem examination, there was oedema between the inner and outer cuticle of the carapace in the area over the gills. This was not seen in diseased crayfish from the farm. Dissection revealed that the cuticular epithelium was pink to purple in colour, oedematous, and sometimes covered with distinctive white spots.

\section{Mortality curve}

The first mortality in the pathogen-injected treatment group occurred $17 \mathrm{~d}$ post injection. On-going 


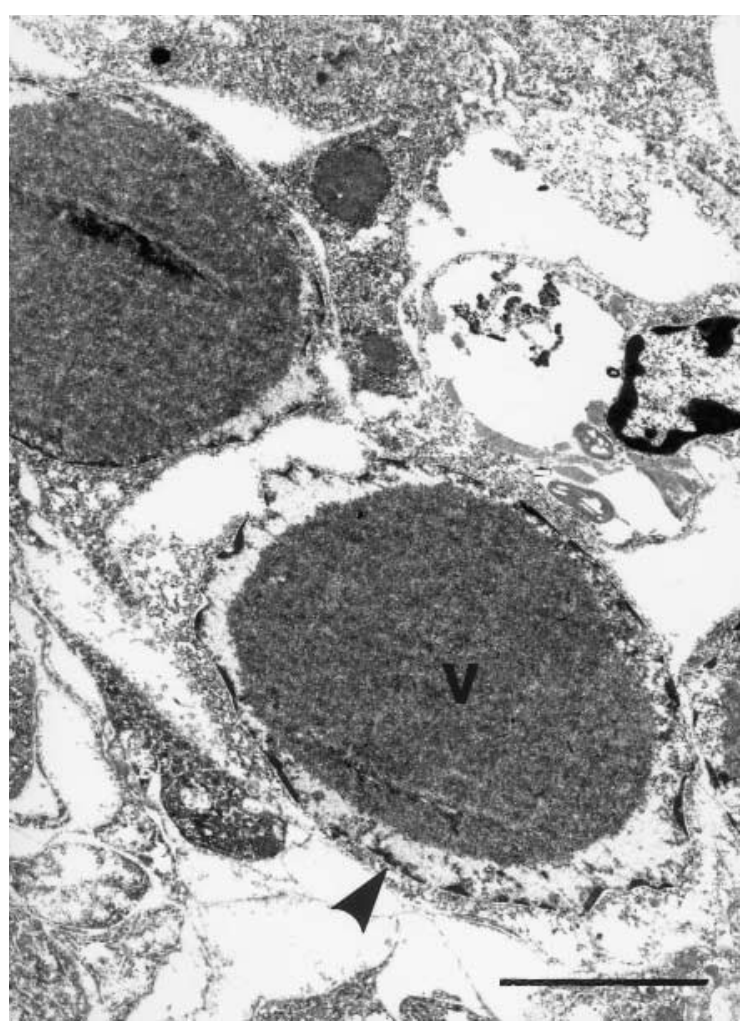

Fig. 2. Cherax quadricarinatus. Electron photomicrograph of an epithelial cell in the eyestalk of crayfish infected with the parvo-like virus. An electron-dense mass (V) containing parvo-like viral particles is located centrally within the enlarged nucleus. Note the margination of heterochromatin at the nuclear membrane (arrowhead). Lead citrate and uranyl acetate. Scale bar $=5 \mu \mathrm{m}$

mortalities occurred in this group for $73 \mathrm{~d}$, when the last remaining crayfish died (Fig. 4). One crayfish died from cannibalism in the injected control group on Day 76 when the experiment was terminated. No mortalities occurred in the non-injected control group.

\section{Histopathology}

Histological examination of the 5 crayfish randomly selected from the pre-trial animals revealed no detectable lesions except for low level infections with $\mathrm{CqBV}$ in the hepatopancreas. These were present in crayfish of all the experimental groups. In addition, 1 crayfish had a reo-like viral infection of the hepatopancreas (Edgerton et al. 2000).

The principal lesions seen in the viral injected crayfish were basophilic, INIBs in cells of the same tissues and tissue types described previously for the farm epizootic. In addition, the retinular, epi-

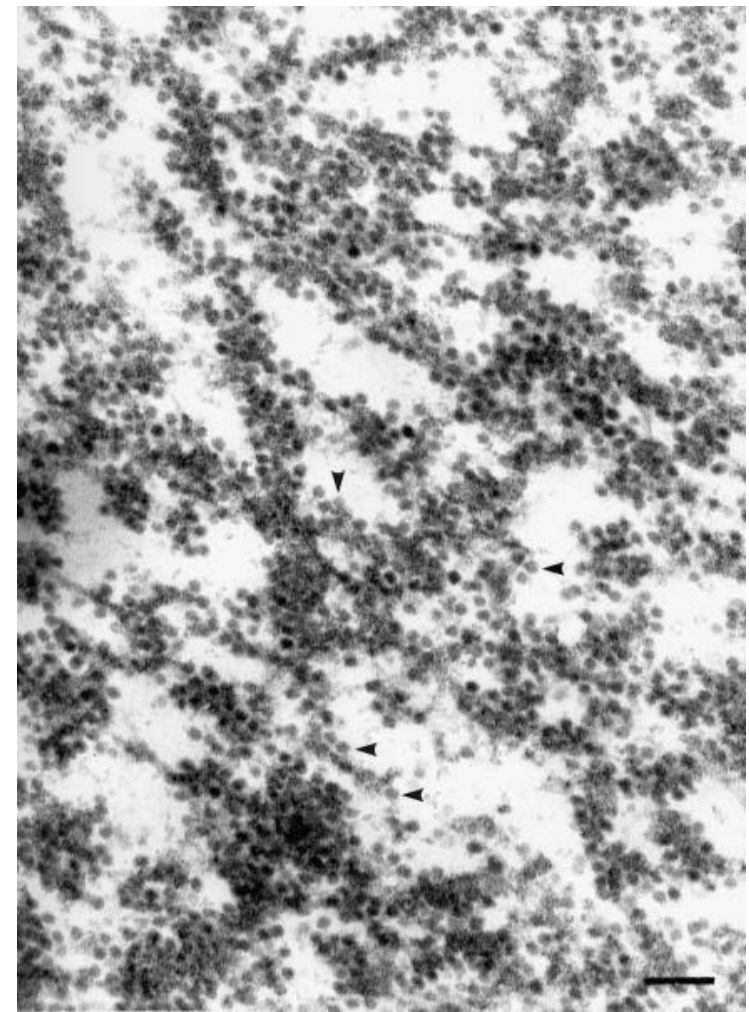

Fig. 3. Cherax quadricarinatus. Electron photomicrograph of an epithelial cell in the eyestalk of crayfish infected with the parvo-like virus. Higher magnification of the electron-dense mass visible in Fig. 1 shows it to consist of numerous viral-like particles, many appearing hexagonal in shape (small arrowheads), with an average diameter of $19.5 \mathrm{~nm}$. Lead citrate and uranyl acetate. Scale bar $=100 \mathrm{~nm}$

corneagenous and proximal cone cells of the eye were occasionally infected. However, unlike crayfish sampled from the farm, a fine granular material that stained basophilic with H\&E was seen in association with scattered focal cellular necrosis in the gills and antennal gland, and in epithelial cells of the foregut and occasionally the midgut and hindgut (Figs. 5 \& 6). The cuticular epithelium was the most heavily infected tissue in both experimental and naturally occurring infections, with scattered focal necrosis and loss of normal columnar structure. This was often accompanied by infiltration of large numbers of haemocytes into the underlying connective tissue.

Histological examination of the unusual oedema in the carapace over the gills revealed that the cuticular epithelium and underlying connective tissue from the inner and outer sides of the carapace were separated from each other by a large space filled with eosinophilic, amorphous proteinaceous material resembling haemolymph (Fig. 7). 


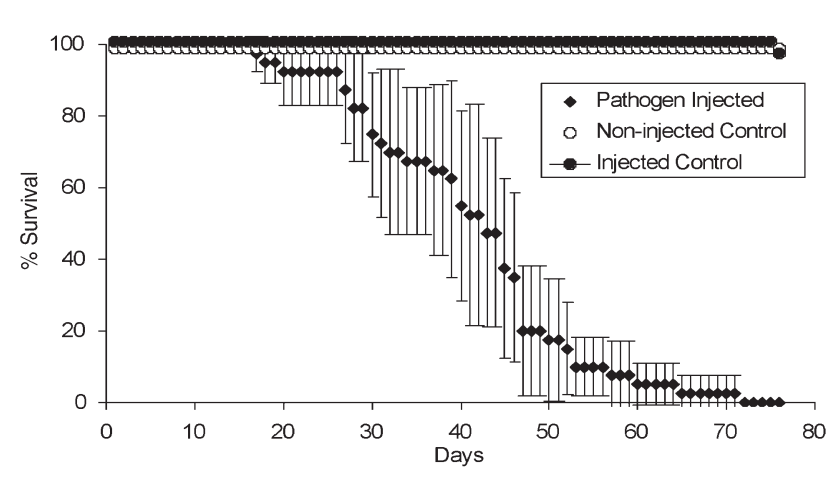

Fig. 4. Survival curve for Cherax quadricarinatus experimentally infected with $C$. quadricarinatus parvo-like virus, showing the mean \% survival \pm SD for the 4 replicate tanks in the infected treatment group compared with the tissue-injected control group and non-injected control group

\section{DISCUSSION}

This is the first virus reported to cause massive, ongoing mortalities in both juvenile and adult cultured Cherax quadricarinatus. Bacteria isolated from the diseased crayfish did not comprise a single or dominant species and they were thus considered to be nonpathogenic.

The cytopathology, morphology and size (average diameter $19.5 \mathrm{~nm}$ ) of the viral particles seen in the infected crayfish suggest it is a member of the Family Parvoviridae, for which virion size ranges from 18 to $25 \mathrm{~nm}$. Cytopathology including enlarged nuclei containing prominent basophilic (with H\&E stain), Feulgen-positive, inclusion bodies with a laterally dis-

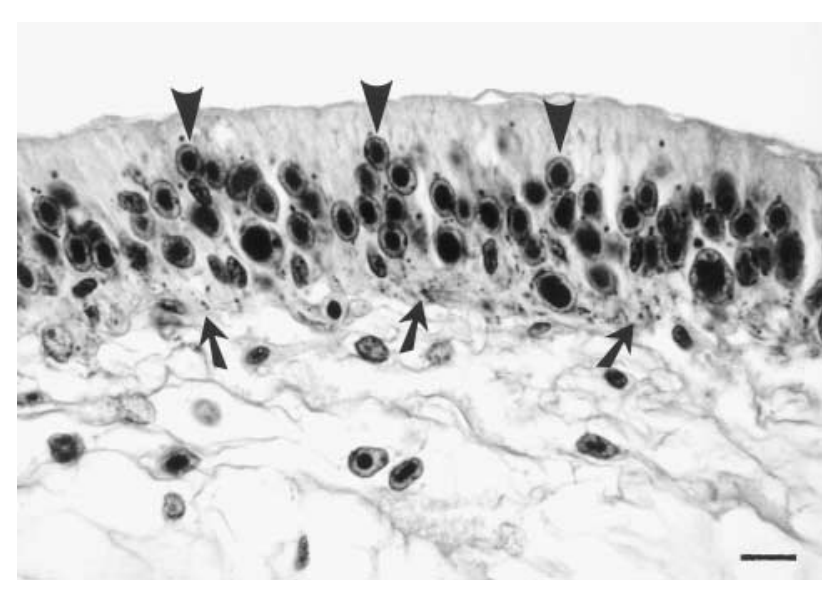

Fig. 5. Cherax quadricarinatus. Foregut epithelium of an experimentally infected crayfish. Numerous 'late'-stage intranuclear inclusion bodies are present within markedly enlarged nuclei (arrowheads). Note the fine, granular, basophilic staining material scattered throughout the tissue (arrows). H\&E. Scale bar $=18 \mu \mathrm{m}$ placed nucleolus is typical of parvo viruses that infect crustaceans. For example HPV, the best-known parvolike virus of cultured marine and freshwater prawns is diagnosed on the basis of such features in hepatopancreatic tubule epithelial cells (Lightner \& Redman 1985, Roubal et al. 1989, Anderson et al. 1990, Bonamai et al. 1995, Lightner 1996). Although the crayfish virus described herein is similar to HPV in its morphology and cytopathology, it is unlike HPV in tissue tropism, since it does not infect hepatopancreatocytes, but other endodermal cells and additionally, cells of ectodermal and mesodermal origin. Thus, we hereafter refer to this virus as Cherax quadricarinatus parvo-like virus or CqPV.

In Australia there have been 2 reports of parvo-like viral infections in freshwater crayfish. The first was a systemic parvo-like virus described from a single moribund Cherax destructor (CdSPV) (Edgerton et al. 1997). The virus produced systemic, Cowdry Type A intranuclear inclusion bodies with multifocal necrosis, in the gills, spongy connective tissues, epicardium and abdominal muscle in $C$. destructor. The inclusions were eosinophilic (with H\&E), Feulgen-negative, and contained icosahedral virions measuring $20.8 \pm 1.2 \mathrm{~nm}$ by TEM. Some of these findings are similar to ours, notably, the presence of intranuclear inclusion bodies in association with multifocal necrosis. However, unlike CdSPV, CqPV produces 'early'- and 'late'-stage inclusion bodies that stain eosinophilic and basophilic, respectively, with H\&E. Furthermore, we did not find inclusion bodies in the epicardium as was reported for CdSPV. CqPV may therefore be a different virus to CdSPV.

The second report was of a putative parvo-like virus from the gills of several moribund Cherax quadricarinatus (Edgerton et al. 2000). Affected gill cell nuclei were enlarged with a vacant nucleoplasm, and no inclusion bodies were present. TEM showed virus-like particles that were $20 \mathrm{~nm}$ in diameter. They were presumed to be parvo-like virions based on the cytopathology and virion size. Edgerton et al. (2000) proposed that the gill lesions represented acutely or chronically infected nuclei. However, we did not see similar gill lesions in any of the C. quadricarinatus that were examined from the farm epizootic or infected with CqPV experimentally. Altogether, the data suggest that CqPV is not the same as the virus described by Edgerton et al. (2000). Further studies including purification of the virus and nucleic acid characterisation will be required for proper classification of CqPV.

Whatever its taxonomic position, our transmission trial showed that CqPV is highly pathogenic to redclaw crayfish and can cause high mortality. The other 2 viruses, CqBV (Anderson \& Prior 1992) and a reo-like virus (Edgerton et al. 2000), found in low numbers in 


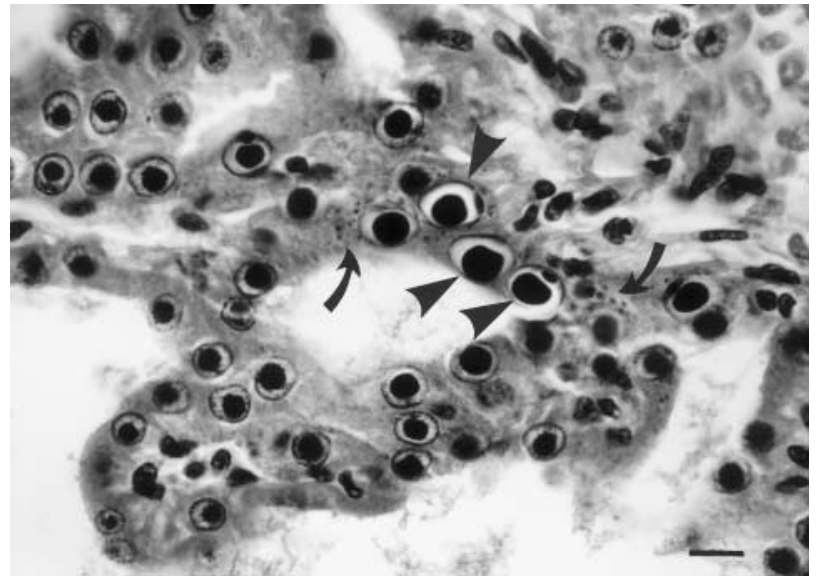

Fig. 6. Cherax quadricarinatus. Antennal gland of an experimentally infected crayfish. Note the numerous infected epithelial cells with nuclear enlargement and prominent basophilic, 'late'-stage intranuclear inclusion bodies. In several cells the nucleolus has been displaced by the inclusion bodies (arrowheads). Fine, granular, basophilic staining material is also visible in the infected tissue (curved arrows). H\&E. Scale bar $=17 \mu \mathrm{m}$

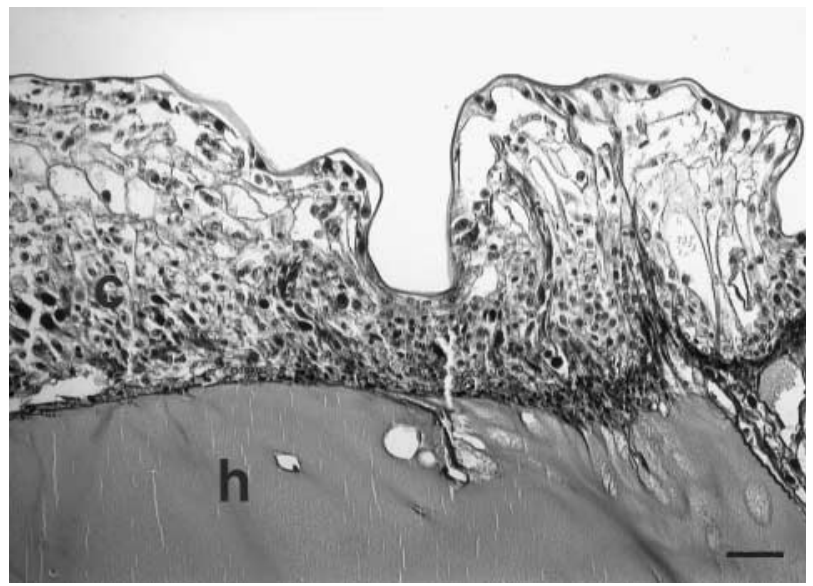

Fig. 7. Cherax quadricarinatus. Cuticle, cuticular epithelium and underlying connective tissue from the inner side of the carapace in the area over the gills from an experimentally infected crayfish. The outer side of the carapace with its cuticle and underlying tissue is not shown but is separated from the inner side of the carapace by a large space filled with oedematous fluid resembling haemolymph (h). Note the loss of normal architecture of the cuticular epithelium. H\&E. Scale bar $=53 \mu \mathrm{m}$

the transmission trial were considered benign since they had no effect on the control groups of crayfish that did not develop CqPV disease.

The origin of the virus is at present unknown. The crayfish farm had not introduced new stock to the farm for over $4 \mathrm{yr}$ and the original broodstock were selected from inland river systems of northern Queensland. The broodstock present at the time of the disease epizootic were all derived from crayfish selected from the resident farm population.

$\mathrm{CqPV}$ has the potential for widespread impacts on the growth and sustainability of the redclaw crayfish industry through the translocation of infected or carrier broodstock to other farms in Australia or to other countries. It has not yet been found in any other redclaw farms or stocks in Queensland. Further research is required, particularly on the natural route of infection, the origin of $\mathrm{CqPV}$, and the susceptibility of other cultured crustaceans. This information would contribute to well-designed on-farm health management programs and risk management in the translocation of redclaw crayfish.

Acknowledgements. This research was supported by the Queensland Department of Primary Industries. Many thanks to the Queensland crayfish farmers for their continued cooperation, support and willingness to allow us farm access. Thanks to Dr. Ian Anderson for his helpful discussion, valuable comments, and for editing and reviewing the manuscript. Thanks to Dr. John Norton, Dr. Annette Thomas, Dr. Anita Gordon, Dr. Greg Storie, Dr. Russell Rodgers and Pat Blackall for review of the manuscript.

\section{LITERATURE CITED}

Anderson IG, Prior HC (1992) Baculoviral infections in the mud crab, Scylla serrata, and a freshwater crayfish, Cherax quadricarinatus, from Australia. J Invertebr Pathol 60:265-273

Anderson IG, Law AT, Shariff M, Nash G (1990) A parvo-like virus in the giant freshwater prawn, Macrobrachium rosenbergii. J Invertebr Pathol 55:447-449

Bancroft JD, Stevens A (1990) Theory and practice of histological techniques, 3rd edn. Churchill Livingston, London

Bonami JR, Mari J, Poulos BT, Lightner DV (1995) Characterization of hepatopancreatic parvo-like virus, a second unusual parvovirus pathogenic for penaeid shrimps. J Gen Virol 76:813-817

Eaves LE, Ketterer PJ (1994) Mortalities in red claw crayfish Cherax quadricarinatus associated with systemic Vibrio mimicus infection. Dis Aquat Org 19:233-237

Edgerton BF, Owens L (1999) Histopathological surveys of the redclaw freshwater crayfish Cherax quadricarinatus in Australia. Aquaculture 180:23-40

Edgerton BF, Owens L, Glasson B, De Beer S (1994) Description of a small dsRNA virus from freshwater crayfish, Cherax quadricarinatus. Dis Aquat Org 18:63-69

Edgerton BF, Owens L, Harris L, Thomas A, Wingfield M (1995) A health survey of farmed redclaw crayfish Cherax quadricarinatus (von Martens), in tropical Australia. Freshw Crayfish 10:322-338

Edgerton BF, Webb R, Wingfield M (1997) A systemic parvolike virus in Cherax destructor. Dis Aquat Org 29:73-78

Edgerton BF, Webb R, Anderson IG, Kulpa EC (2000) Description of a presumptive hepatopancreatic reovirus, and a putative gill parvovirus in the freshwater crayfish Cherax quadricarinatus. Dis Aquat Org 41:83-90

Hayat MA (1970) Principles and techniques of electron- 
microscopy. In: Biological applications, 1. Van Nostrand Reinhold Company, New York

Ketterer PJ, Taylor DJ, Prior HC (1992) Systemic rickettsialike infection in farmed freshwater crayfish, Cherax quadricarinatus. In: Shariff M, Subasinghe RP, Arthur JR (eds) Diseases in Asian aquaculture, I. Fish Health Section, Asian Fisheries Society, Manila, p 173-179

Lightner DV (1996) A handbook of pathology and diagnostic procedures for disease of penaeid shrimp. World Aquaculture Society, Baton Rouge, LA

Lightner DV, Redman RM (1985) A parvo-like virus disease of penaeid shrimp. J Invertebr Pathol 45:47-53

Medley PB, Jones CM, Avault JW (1994) A global perspective of the culture of Australian redclaw crayfish, Cherax quadricarinatus: production, economics and marketing. World Aquacult 25(4):6-13

Editorial responsibility: Timothy Flegel, Bangkok, Thailand
Owens L, McElnea C (2000). Natural infection of the redclaw crayfish Cherax quadricarinatus with presumptive spawner-isolated mortality virus. Dis Aquat Org 40: $219-223$

Owens L, Haqshenas G, McElnea C, Coelen R (1998) Putative spawner-isolated mortality virus associated with mid-crop mortality syndrome in farmed Penaeus monodon from northern Australia. Dis Aquat Org 34:177-185

Paynter JL, Lightner DV, Lester RJG (1985) Prawn virus from juvenile Penaeus esculentus. In: Rothlisberg PC, Hill BJ, Staples DJ (eds) Second Australian National Prawn Seminar. NPS2, Cleveland, p 61-64

Roubal FR, Paynter JL, Lester RJG (1989) Electron microscopic observation of hepatopancreatic parvo-like virus (HPV) in the penaeid prawn, Penaeus merguiensis de Man, from Australia. J Fish Dis 12:199-201

Submitted: October 25, 2001; Accepted: April 11, 2002

Proofs received from author(s): July 2, 2002 